\title{
VLAANDERENS GLORIE: DIE PRIMITIEWE EN BRUEGEL
}

Drie keer sou ons stamland Vlaandere 'n aansienlike plek in die kunsgeskiedenis van die wêreld inneem. Die eerste keer in die $15 \mathrm{e}$ eeu of eeu van Bourgondië met die "sogenaamde" Vlaamse Primitiewe, 'n tweede keer in die 17e eeu of eeu van die Vlaamse Barok met kunstenaars soos Rubens, Van Dijck en Jordaens en 'n derde keer, in die $20 \mathrm{e}$ eeu, met ekspressioniste soos Permeke, Jespers en Servaes.

Ewe min as Goties, wat barbaars en Geus, wat skooier beteken, is primitief 'n vleinaam. Maar ook dié naam is so ingeburger dat die kunsgeleerdes daar maar net "sogenaamde" aan kan toevoeg, want dié kuns van die "sogenaamde" sg. Primitiewe was binne sy grense en oogmerke en selfs in sy tegniek volmaak. Die Kruisafneming van Rogier van der Weyden in Madrid, 'n werk wat deur dr. Beets in Van Gelder se Kunstgeschiedenis der Nederlanden „klassiek" genoem is, is geometries-simmetries in die perfeksie opgebou en dit is in die rolprent van Paul Haesaerts: De gouden eeuw van de Vlaamse Schilderkunst, wat ook aan die Potchefstroomse Universiteit vir Christelike Hoër Onderwys vertoon is, meesterlik gewys. Dirk Bouts gee in sy Laatste Avondmaal van die Leuvense Sint Pieterskerk 'n perspektiwies onfeilbaar gekonstrueerde Gotiese kamer weer. Nee, primitief is die kuns van die sg. Vlaamse Primitiewe allermins.

Trouens was Vlaandere in die Ryk wat die hertoë van Bourgondië van 1384 af, uit die erfenis van Lodewyk van Male begin opbou het, die vooruitstrewendste, beskaafste en rykste gewes. In hierdie Bourgondiese Benelux lê die swaartepunt in die Suide en nadat Parys deur die Honderdjarige Oorlog met Engeland so 'n gevoelige knou gekry het, bloei die SuidNederlandse stede op: Brugge word die wêreldhawe van die Weste, Gent, die nywerheidstad, Brussel die setel van die aristokrasie, Leuven die oudste universiteitstad van die Nederlande. Geen wonder nie dat hierdie stede wat deur immigrasie uit die Noorde en intrek van vreemdelinge uit die hele Europa nog groter, magtiger en veral ryker geword het, elk hulle eie skilderskool sou hê. Nie net die burgers of hoëre amptenare nie van wie die name en beeltenisse saam met die meesterwerke vereeuwig is, maar ook die hertoë self gee die voorbeeld. So neem Filips die Stoute nie net die graafskap Vlaandere van 
sy skoonvader oor nie, maar ook Lodewyk se hofskilder Melchior Broederlam, wat aldus die kans kry om ook in Hesdin, Parys en Dijon te gaan werk. $\mathrm{Hy}$ is nog 'n skakel met die skool van die Frans-Vlaamse miniaturiste. Uit hierdie kuns van boekversierders het die Nederlandse skilderkuns ontstaan, net soos die Italiaanse uit die al fresco of muurskildering voortgekom het.

Ook Jan van Eyck is miniaturis voor hy hofskilder van Filips die Goede word. Die skerm-gewyse indeling van die landskap in sy meesterwerk De aanbidding van het Lam Gods van 1432 wys nog daarop. Hierdie werk uit die Gentse Sint Baafskerk is die resultaat van skerp waarneming, ook van voorwerpe van daaglikse gebruik, wat deur hulle glanskleure lewe en betekenis gee aan die geheel en eintlik die hooftema: hulde aan die Lam, bevestig. So ook die bolspieël in Arnolfini en zijn vrouw uit die Londense National Gallery. In sy sirkel vat hy die hele reghoekige vertrek saam, waarvan die intimiteit: warmrooi egtelike bed en leunstoel, geel houtskoene, ' $n$ hondjie, 'n paar appels, 'n hulde is aan die egtelike trou. Hierdie hooftema word verder bevestig deur die verbondenheid van die egpaar met sy omgewing. Soos in ander werke wat die skilder beskeie met: Als ich kan, d.w.s. so goed as ek kan, onderteken, is hier die materie trou en reël weergegee: koper is koper en hout is hout en die koloriet het 'n warme, intieme tonaliteit. Ook deur 'n gehele, realistiese „oop uitbeelding” van ruimte en atmosfeer het Van Eyck die Nederlandse kuns tot 'n eerste hoogtepunt gevoer. In sy styl werk ook sy broer Hubrecht, van wie die bestaan wel eens betwis is, en in sy voetspoor volg 'n hele aantal Brugse skilders o.w. vernaamlik Petrus Christus.

In Brussel triomfeer die hartstogtelike, sterk dramatiespatetiese stadskilder Rogier van der Weyden. Sy meesterwerk is die reeds aangehaalde Kruisafneming in die Prado te Madrid. Morele en liggaamlike uitdrukking van smart bereik hier 'n hoogtepunt wat in die Nederlandse kuns nooit meer sou oortref word nie. Ondanks liriek en dramatiek is die werk van $V a n$ der Weyden monumentaal danksy 'n koel berekende, eksak gebalanseerde konstruksie. Nie alleen Brusselse skilders soos Vrancke van der Stockt sluit by hom aan nie, maar ook die jong Memling, David, die Duitser Schüchlin en selfs Dirk Bouts. 
Dirk Bouts is die leier van die Leuvense groep. Ook hy is stadskilder. Met sy Laatste Avondmaal in die Sint Pieterskerk te Leuven is hy die grondlegger van die Nederlandse groepsportret wat sy hoogtepunt by Rembrandt vind. In sy Weg naar het Paradijs uit Rijsel is Bouts 'n baanbrekende landskapskilder. Die kunsmatige plan-indeling waardeur dele van die landskap deur skerms geskei is, soos op 'n toneelverhoog, het hy hier laat vaar. Daarmee het 'n hinderlike herinnering aan die kuns van die miniaturiste, verdwyn.

Die mees poëtiese van die Vlaamse Primitiewe is Hans Memling. $\mathrm{Hy}$ is minder dramaties, rustiger en eleganter, intiemer en sierliker as sy meester Rogier van der Weyden. Die Sint Janshospitaal in Brugge bewaar baie van sy werke, wo. die bekende Ursulaschrijn. Sy madonna's is vroom en dromerig. Daarteenoor staan die ekspressiewe kuns van Hugo van der Goes, 'n hernuwer van ikonografiese temas deur invoering van tipes uit die volk in sy Aanbidding der herders te Florence. Ook sy apostels is „demokraties". Godsvrug en ekstase verheerlik egter die deur die harde lewe deurkerfde gesigte. Die laaste grootmeester van die Brugse skool is Gerard David. Hy was getroud met die skilderes Cornelia Cnoop. Hy ondergaan verskeie invloede: Memling, Van der Goes en Van der Weyden, maar hy weet hoe om dit alles harmonies te verbind. Sy hoofwerk is Het doopsel van Christus in die museum te Brugge, 'n mylpaal in die ontwikkeling van die Nederlandse landskapskildering: die landskap is in verhouding tot die figure gekonstrueer, hulle hang organies met die landskap saam. David word nagevolg deur Isenbrant, Van Eeckele, Cornelis en Benson. Sy invloed reik tot ver in die $16 \mathrm{e}$ eeu.

Inmiddels versand die seehawe van Brugge en gaan die stad ekonomies ten onder. Handel en kuns soek 'n nuwe sentrum in Antwerpen, waar Italiaanse, dus minder nasionale invloede gaan oorheers. Inmiddels het die Ekspansie van die Vlaamse Kuns begin. Die skole van Noord-Nederland en Frankryk, die Rynland en Switserland, Spanje en Portugal, tot selfs die van Napels en Sicilië in Europa se tweede kunsland Italië, kom onder sy invloed. Justus van Gent werk in Urbino, Meester Michiel en Juan de Flandes in Spanje, Maelwael in Parys en Hendrik Bellechose in Dijon, waar ook die werk van beeldhouer Klaas Sluter tot stand gekom het.

Sonder hierdie skitterende ,eeu van Bourgondië" is die 
latere ontwikkeling, sowel van Noord- as van Suid-Nederland, ook op die gebied van die kuns, ondenkbaar. Die sogenaamde Vlaamse Primitiewe wat ons nie almal (daar is bv. drie Boutse, drie Van der Weydens en 'n tiental anonieme „Meesters") en seker nie volledig kon behandel nie, is die grondleggers van die Dietse Kuns, waarvan die ekspansiekrag die eintlike politieke mag van Holland en Vlaandere ver sou oortref. Die Vlaamse Primitiewe het aan ons stam 'n erfenis nagelaat, wat die wêreld ons beny, waar ook die Afrikaner trots op kan wees, maar wat ons veral, almal, en seker die kunstenaars onder ons, waardig moet wees.

Deur die huwelik van Maria van Bourgondië met Maximiliaan van Oostenryk in 1477 gaan die Bourgondiese erflande na die huis van Habsburg oor. Maria se seun, Filips die Skone, trou met Johanna die Waansinnige van Kastilië. Uit die huwelik word Karel V gebore, wat in 1516 Spanje van sy moederlike grootvader, Ferdinand van Aragon, erf. Daarmee het die Nederlande onder Spanje gekom, waarteen hulle in die tweede helfte van die $16 \mathrm{e}$ eeu sou rebelleer. Die eerste jare van die opstand sou met die laaste lewensjare van Pieter Bruegel saamval.

Sy tydgenote en onmiddellike voorgangers lewe en werk in die ban van die Italianisme. Van die "Primitiewe" waarheid, eenvoud, stilte en kontemplasie is geen sprake meer nie. Tog is daar onder hulle wat as nasate van die roemryke Vlaamse Primitiewe kan beskou word: Quinten Metsys, Jan Gossaert, Joos van Cleve, Barend van Orley, Jan Provoost, Jan Mostaert, Joachim Patinir en Hierronymus Bosch. Maar dit sou Pieter Bruegel de Oude self wees wat so kordaat na tradisioneel Nederlandse tegnieke teruggryp. Van Bosch, oorlede in 1516, neem hy die breë horisonne met riviermonding, en iets uit sy wêreldbeeld oor. By Bosch, wat deur sy droomgesigte en hallusinasies 'n soort psigoanalities-surrealis is, word die wêreld deur die duiwel beheers. Sy „duvelrieën” is egter nog laat-middeleeus, terwyl dit by Bruegel, 'n humanis onder die humaniste van sy tyd, die menslike dwaasheid is wat die wêreld regeer. Die sonde het die mens tot 'n nar onder die narre gemaak. Sy sosiale wêreld is die "Verkeerde Weereldt". Beïnvloeding deur Erasmus se Lof van die Sotheid kan aan hierdie opvatting nie vreemd wees nie.

Aan Patinir ontleen Bruegel die sg. Panoramiese landskap, 
'n landskap wat uit 'n hooggeleë punt bekyk word en hom in die rigting van 'n eweneens hooggeleë horison uitstrek.

Bruegel word omstreeks 1525 gebore in 'n dorp van die Limburgse Kempen, ' $n$ heideland wat tans deur die BelgiesNederlandse grens deursny word. Hy gaan in die leer te Antwerpen by sy latere skoonvader Pieter Coecke van Aelst, 'n oortuigde Italianis, en geen wonder dat die jong kunstenaar die gebruiklike Italië-reis maak nie. Die Romeinse rünes het die skilder nie geweldig beïndruk nie, maar hy ervaar wat Karl Tolnai 'n ,Alpenerlebnis" noem. In sy Schilderboeck vertel Van Mander dat die kunstenaar ,in d'Alpes wesende, al die berghen en rotsen had in gheswolghen, en t'huys ghecomen op doecken en Penneelen uytghespoghen hadde". Alpelandskappe vind ons inderdaad in die prente wat hy vir die Antwerpse etser en gravure-handelaar Hiëronymus Cock geteken het. Uit dié jare stam ook sy allegoriese plate soos De grote vissen eten de kleinen waarop figuurtjies uit die "helse" drome van Bosch rondswerf.

In sy vroeë skilderye, De spreekwoorden, De strijd tussen Vasten en Vastenavond en De kinderspelen, krioel honderde klein gedaantes teen 'n hoë horison. Dié werke is ware ensiklopedieë van volksgebruike, en folkloriste het hulle dankbaar as studie-objek aanvaar. Van hierdie ensiklopediese werke is Dulle Griet, 'n ontsettende dodedans, die hoogtepunt. Hier het die onrus en dadedrang van die mens 'n duiwelse chaos geskep.

Eers in sy latere werke ontdek Bruegel die waarde van die kleurvak. Breë rugge van boere in 'n eenvoudige en afdoende kleur, geometriese kleurblokke soos die geel koring. lande in De oogst, sterk verkorte, na die hoogte gerigte perspektief soos in Luilekkerland, word met graagte deur kubiste aangehaal as prae-figurasies van hulle kunsrigting.

Dit wat die tegniek betref, maar watter rykdom aan inhoud: ydelheid van die menslike hoogmoed in De Babeltoren; ureedheid van die (Spaanse) soldateska in De moord der Onnozele Kinderen; die kreupele wat die dans wil lei in De boerendans; die nutteloosheid van 'n verwaande "ruimtereis" in die Val van Ikaros, waar op die voorgrond 'n boer rustig verder ploeg en nie eens opkyk nie, ewe onverskillig teenoor die ramp van één mens soos die lewenskragtige natuur self; blinde en verblinde leierskap in die Parabel van de blinden waar grys tinte laat dink aan die kleur van dooie as. Te midde van die onverwoes- 
baarheid van die toneel van die natuur gaan die blindes hul ondergang tegemoet.

In 1566 neem die edeles van die Eedverbond die naam "Geuse" aan. 1567 hou die hertog van Alva sy intrede. Dadelik voel Bruegel, wat in Brussel, die brandpunt van die verset woon, die komende tragedie aan. Hy skilder sy Ekster op de galg. Te midde van 'n natuur wat volgens hom redelik, „organies" en kosmies-samehangend is, rys die galg op, seëvierende simbool van dwaasheid, redeloosheid, misdadigheid en sondigheid van die ",anorganiese" mens.

In 1569 sterf Bruegel en word in die Brusselse Kapellekerk begrawe.

Bruegel, wat deur Van Ostaijen ,de meest objectief kosmiese schouwer onder alle noordse kunstenaars" genoem word, is nasionaal en internasionaal. Wie in hom maar "Pier den Drol" of die "Boerenbruegel" sien - hy skilder die boer omdat hy saam met die kind in 'n "natuurlose" mensewêreld nog die naaste aan die natuur staan - het geen insig hoegenaamd in die tragedie van die Vlaamse volk nie, 'n tragedie wat vir Bruegel ook die van die hele mensegeslag was. Aldus is hy die mees Vlaamse maar tewens die universeelste van alle Dietse Kunstenaars.

Die tradisie van so 'n man kon nie sterf nie, en weens sy ekspressivisme is daar baie onder die Vlaamse ekspressioniste wat by hom aansluit: Laermans, Jakob Smits, Gustaaf van de Woestijne, Evarist de Buck, Valerius de Saedeleer en die Rubens van die Vlaamse ekspressionisme: Constant Permeke.

P.U. vir C.H.O.

A. A. F. Teurlinckx.

(Met vriendelike vergunning van die S.A.U.K.). 